CONVERGENCE OR DIVERGENCE? 


\title{
Convergence or Divergence?
}

Britain and the Continent

\author{
Jeremy Black \\ Reader in History \\ University of Durham
}

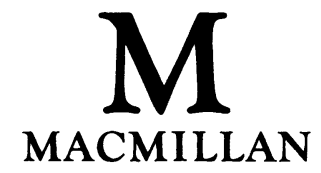


(C) Jeremy Black 1994

All rights reserved. No reproduction, copy or transmission of this publication may be made without written permission.

No paragraph of this publication may be reproduced, copied or transmitted save with written permission or in accordance with the provisions of the Copyright, Designs and Patents Act 1988, or under the terms of any licence permitted limiting copying issued by the Copyright Licensing Agency, 90 Tottenham Court Road, London WIP 9HE.

Any person who does any unauthorised act in relation to this publication may be liable to criminal prosecution and civil claims for damages.

First published 1994 by

THE MACMILLAN PRESS LTD

Houndmills, Basingstoke, Hampshire RG21 2XS

and London

Companies and representatives

throughout the world

ISBN 978-0-333-60859-3 ISBN 978-1-349-23345-8 (eBook)

DOI 10.1007/978-1-349-23345-8

A catalogue record for this book is available

from the British Library 
For Dan and Stella Hollis 


\section{Contents}

List of Maps viii

$\begin{array}{ll}\text { Preface } & \text { ix }\end{array}$

List of Abbreviations $\quad$ xi

1 Introduction 1

2 Rome and the Anglo-Saxons 6

3 Norman Conquest and Medieval Empires, 1066-1485 43

4 The Sixteenth and Seventeenth Centuries 100

$5 \quad 1714-1815 \quad 143$

$\begin{array}{lrl}6 & 1815-1914 & 174\end{array}$

$\begin{array}{lll}7 \quad 1914- & 213\end{array}$

8 Conclusions 261

$\begin{array}{ll}\text { Notes } & 271\end{array}$

$\begin{array}{ll}\text { Bibliography } & 307\end{array}$

$\begin{array}{ll}\text { Index } & 309\end{array}$ 


\section{List of Maps}

1 Britain and Western Europe, $400 \quad 10$

2 Britain and Western Europe, 814

3 Britain and Western Europe, 1000

4 Britain and Western Europe, 1030

5 Britain and Western Europe, 1100

6 Britain and Western Europe, 1189

7 Britain and Western Europe, 1360

8 Britain and Western Europe, 1550

9 Britain and Western Europe, 1721

10 Britain and Western Europe, 1812

11 Britain and Western Europe, 1815

12 Britain and Western Europe, 1914

13 Britain and Western Europe, 1958- 239 


\section{Preface}

The relations between Britain and the Continent have been central to my work, linking publications on such diverse topics as international relations, tourism and the press perception of foreign countries. My teaching of and writing on British history have constantly been illuminated by a European perspective. Most of my work has been devoted to the period 1688-1793 and this book represents an attempt to provide a longer perspective to the question of relations which I believe to be crucial to an understanding of British history.

In the course of this study I have accumulated a number of debts. I would like to thank the British Academy and the Staff Travel and Research Fund of Durham University for supporting my research. I have benefited from the comments of Simon Adams, Walter Arnstein, Benjamin Arnold, Stuart Ball, Ross Balzaretti, Eugenio Biagini, John Blair, George Boyce, P. J. Casey, Jonathan Clark, John Derry, Bill Dohar, Susan Doran, David Eastwood, Barbara English, Alan Ford, Gerald Harriss, Margaret Harvey, Paul Harvey, Colin Haydon, Nicholas Henshall, David Hey, Ralph Houlbrooke, Norman Housley, Daniel Johnson, Ken Lawson, Simon Lloyd, David Loades, Victoria Ortenberg, Jon Parry, Bernard Porter, Michael Prestwich, Nigel Ramsay, David Rollason, Jim Sack, Nigel Saul, Geoffrey Searle, Henry Summerson, Roger Virgoe, Bruce Webster, Ann Williams, Philip Williamson, John Young, and Patrick Zutshi on earlier drafts of sections of this study. I would like to thank David Sturdy for advice on particular points. A section was delivered as a paper at Adelaide, Auburn, Auckland, Birmingham, Brown, Canterbury, East Anglia, Leeds and Massey Universities, at Downing, Peterhouse and Stillman Colleges, to the Stubbs Society, and to the annual conference of the British Society for Eighteenth-Century Studies and I am most grateful for all the suggestions that were made. I owe a great debt to Wendy Duery for her efficient assistance. I am necessarily aware of the tentative nature of many of my conclusions and the possibility of suggesting different interpretations. I am also aware that treating a subject of this magnitude, not least in a relatively short work, is a difficult task and that much of importance has been omitted. Rather, 
however, than seeking the safer pastures of detailed archival research (difficult as that course itself can be), I have preferred to offer what I hope is a reasoned account of the background to one of the major issues facing Britain today.

Newcastle

JEREMY BLACK 


\section{List of Abbreviations}

BIHR Bulletin of the Institute of Historical Research

EcHR Economic History Review

EHR English Historical Review

HJ Historical Journal

TRHS Transactions of the Royal Historical Society 